\title{
Assessment of zinc status
}

\author{
BY R. P. H. THOMPSON \\ St Thomas' Hospital, London SEl 7EH
}

Although the gross skin rash of profound zinc deficiency is well documented in patients with acrodermatitis enteropathica, glucagonoma and severe deprivation, this striking clinical manifestation is rare. Unfortunately, other clinical signs are variable and difficult to assess, and so we seek a quantitative assessment of body $\mathrm{Zn}$ stores (Solomons, 1979).

There are two different measurements for assessing the status of a trace element or vitamin in the body; namely, either the total body content, or an indirect measure of an appropriate body content. There is, however, little work on directly measuring the total body content of $\mathrm{Zn}$ in man, although nearly 40 years ago Widdowson et al. (1951) estimated the content of three adult cadavers. These were of two patients who had died of chronic disease and one emaciated suicide, and so the $\mathrm{Zn}$ contents were probably not normal. Nevertheless, the calculated whole-body contents were $0.75,1.2$ and $2.0 \mathrm{~g}$. These macabre studies have not been repeated, but it may be possible to extrapolate less directly from samples of bone and muscle, in which most $(90 \%)$ of the $\mathrm{Zn}$ is contained, after calculating the skeletal and muscle mass. In small animals total content can be obtained directly (Jackson et al. 1982), but in man an indirect measure has to be used.

However, demonstration of an estimated body content below normal levels may not indicate deficiency. Thus, in starvation as tissues waste and urinary $\mathrm{Zn}$ increases (Elia et al. 1984), the body $\mathrm{Zn}$ content falls appropriately, and the body is depleted. Deficiency, as indicated by skin rashes or failure to grow, does not occur until refeeding when growth returns and requirements increase, as Golden \& Golden (1981) reported for $\mathrm{Zn}$ in children with malnutrition in Jamaica, and Paton (1981) for vitamins in adults in Belsen. Deficiency might, therefore, be defined as an inappropriate reduction of whole-body content leading to abnormal physiological or biochemical functions that are reversed simply by supplementation with $\mathrm{Zn}$. Thus, depletion is always associated with deficiency, but not always vice versa.

In clinical practice, however, a simple measure is required rapidly and reliably to assess $\mathrm{Zn}$ status in an individual. Reduction of the mean levels of groups of patients is useful only for research studies. Many attempts have been made to assess $\mathrm{Zn}$ status with static measurement of levels in a body fluid or tissue, but these demonstrate tissue or fluid depletion, which may or may not reflect levels in other tissues. This is particularly so if only a diseased tissue is measured, such as liver biopsy specimens in patients with liver disease (Keeling et al. 1981), because infiltration with collagen, fat etc. and loss of hepatocytes dissociate the results from those of other tissues.

\section{STATIC MEASUREMENTS}

1. Plasma. $\mathrm{Zn}$ is an intracellular element and so only $0.01-0.02 \%$ of the body content circulates in plasma where it is highly bound to plasma proteins, particularly albumin. In addition $\mathrm{Zn}$ is rapidly drawn into the liver and spleen in response to cytokines released during stress and infection. The levels fall during normal pregnancy (Meadows et al. 
1981), especially if the plasma volume expands appropriately (Tuttle et al. 1985). Hence, it is not surprising that plasma levels, particularly in an individual, give limited information on body $\mathrm{Zn}$ status (Solomons, 1979). This is similarly true for potassium, which is also intracellular (Flear et al. 1957). In addition, $\mathrm{Zn}$ rises after meals, interestingly falls below the baseline $2 \mathrm{~h}$ after a meal, rises on short-term starvation (Elia et al. 1984) and undergoes a diurnal rhythm. Plasma levels are also correlated with albumin levels, to which $\mathrm{Zn}$ is chiefly bound in plasma, in several diseases (Solomons, 1979; Keeling et al. 1980; Tuttle et al. 1985; Pironi et al. 1987; Ainley et al. 1988; Goode et al. 1989b), and this explains the high frequency of $\mathrm{Zn}$ deficiency reported in so many chronic diseases. Golub et al. (1984) have elegantly demonstrated that plasma Zn levels fall in $\mathrm{Zn}$-deprived pregnant monkeys only if they do not lose weight. If they waste, the $\mathrm{Zn}$ released from tissues, probably chiefly muscle, maintains plasma levels. Similarly, plasma levels rise in wasting Zn-deprived rats (Giugliano \& Millward, 1984) and in growing marasmic children (Golden \& Golden, 1981). Serum levels differ from those of plasma (Hambidge, 1988).

Unfortunately, the avalanche of papers relying entirely on plasma $\mathrm{Zn}$ levels continues, and yet their conclusions can only be limited. Nevertheless, in both simple human (Buerk et al. 1973; Hess et al. 1977; Prasad et al. 1978; Baer \& King, 1984) and animal (Jackson et al. 1982; Crofton et al. 1983; Everett \& Apgar, 1984; Giugliano \& Millward, 1984) experimental $\mathrm{Zn}$ deficiency plasma levels fall.

2. Urine. In humans about $0.5 \mathrm{mg} \mathrm{Zn}$ is normally excreted in urine daily. This falls during Zn deprivation (Prasad et al. 1978; Baer \& King, 1984), presumably as the level of non-protein-bound $\mathrm{Zn}$ in plasma falls, and hence, together with increased intestinal absorption, healthy adults on bioavailable diets can equilibrate even on an intake of only 2-3 mg/d (Buerk et al. 1973). However, since urinary $\mathrm{Zn}$ is greatly increased, for instance, in some patients with cirrhosis, possibly due to decreased hepatic extraction of the surge of absorbed $\mathrm{Zn}$ after a meal (Keeling et al. 1981), or in patients who are wasting (Fell et al. 1973; Jackson et al. 1981), or in diabetes mellitus (Kinlaw et al. 1983) or due to ethambutol (King \& Schwartz, 1987) or during refeeding (Elia et al. 1984) or receiving intravenous $\mathrm{Zn}$, its level is not reliable. There are also further problems in obtaining complete urinary collection, and in preventing contamination (Solomons, 1979). Urinary excretion may depend on the concentration of plasma and urine free amino acids (Yunice et al. 1978).

3. Liver. Zn levels in liver fall in experimental Zn deficiency (Jackson et al. 1982; Giugliano \& Millward, 1984; Keen et al. 1988), as do the levels and hepatic extraction of $\mathrm{Zn}$ in liver disease in man (Keeling et al. 1981), but measurement of small biopsy samples, the effects of fat infiltration or frank liver disease, and the invasive nature of the test will always limit its use.

4. Muscle. About $60 \%$ of body $\mathrm{Zn}$ is in skeletal muscle. In man $\mathrm{Zn}$ levels are reduced in biopsy specimens in pregnancy (Meadows et al. 1983a) and liver disease (Jones et al. 1981). However, muscles are not homogeneous (Jackson et al. 1982; Giugliano \& Millward, 1984). In the commonly used laboratory rat, experimental deficiency does not reduce levels in muscle (Jackson et al. 1982; Giugliano \& Millward, 1984; Senapati, 1986), nor the pig (Crofton et al. 1983), although they fall in the cat (Jacobson et al. 1986). In any case, many clinicians find muscle biopsy needles rather invasive!

5. Bone. Bone contains about $30 \%$ of body $\mathrm{Zn}$. Based on experimental deficiency in the rat (Giugliano \& Millward, 1984; Milne et al. 1985a: Senapati, 1986) low levels in 
bone should indicate depletion of 'stores' of $\mathrm{Zn}$, when bone becomes avid for $\mathrm{Zn}$ (Senapati, 1986). This has been little studied in man, although the uptake of $\mathrm{Zn}$ may be increased in cirrhosis (Gvozdanovic et al. 1982). Bone structure is heterogeneous and so the core of tissue obtained with the needle may not be uniform. Nevertheless, needle bone biopsy specimens are routinely taken to diagnose osteomalacia, and this method needs further study.

6. Erythrocytes. These are readily available and contain a large amount of $\mathrm{Zn}$, which is chiefly fixed within carbonic anhydrase (EC 4.2.1.1). Not surprisingly, therefore, erythrocyte $\mathrm{Zn}$ concentrations do not reliably change in experimental (Milne et al. 1985a; Apgar \& Fitzgerald, 1987) and clinical deficiency (Prasad et al. 1978; Solomons, 1979; Keeling et al. 1980; Baer \& King, 1984). It is possible that the small quantities of $\mathrm{Zn}$ in the erythrocyte membrane may reflect levels in other tissues, and this is being explored in our laboratory.

7. Leucocytes. Leucocytes are nucleated and their $\mathrm{Zn}$ content should reflect the levels of other tissues (Lindh \& Johansson, 1987). Mixed leucocytes, and more recently, polymorphonuclear leucocytes (neutrophils) have, therefore, been used to measure $\mathrm{Zn}$ status in man. Given the heterogeneity of the cells, the results have been surprisingly consistent, and seem to reflect deficiency in a variety of diseases, ranging from experimental human deprivation (Prasad et al. 1978) to intra-uterine growth retardation (Meadows et al. 1981, 1983b; Simmer \& Thompson, 1985; Wells et al. 1987) and the elderly (Goode et al. 1989c; Senapati et al. 1989). Leucocytes are easily obtained, but the separation procedure is difficult and lengthy. Haematological disorders can affect levels (Fredricks et al. 1964).

Polymorphonuclear leucocytes are probably now the preferred subpopulations to analyse (Goode et al. 1989a), since monocytes are heterogeneous, are more difficult to separate, are more easily contaminated with Zn-rich platelets (Milne et al. 1985b; Wallwork, 1987) and have longer and variable half-lives. Since monocytes contain more Zn than polymorphonuclear leucocytes (Simmer \& Thompson, 1985; Goode et al. $1989 a$ ), changes in their relative numbers can affect levels in mixed cells as, for instance, occurs in normal pregnancy as the proportion of polymorphs falls (Meadows et al. 1981). In addition, in some experimental animals $\mathrm{Zn}$ deficiency does not lower levels (Crofton et al. 1983; Milne et al. 1985a; Apgar \& Fitzgerald, 1987), although it does so in the cat (Jacobson et al. 1986). Since in the rat, muscle $\mathrm{Zn}$ levels also do not fall in deficiency, the good correlations with levels in muscle in man (Jones et al. 1981) were initially unexpected. In the housebound elderly, leucocyte $\mathrm{Zn}$ levels correlate with $\mathrm{Zn}$ balance (Bunker et al. 1987). Recent work has shown muscle and leucocyte $\mathrm{Zn}$ levels to be correlated in surgical patients (Goode et al. 1989b). Finally, the reduction in mean levels in diseases such as polycythaemia (Simmer et al. 1987) and diabetes mellitus (Pai \& Prasad, 1988) suggests that leucocyte levels may not always simply reflect whole-body levels. The reasons for levels falling in the leucocyte, therefore, need further study.

8. Non-protein-bound $\mathrm{Zn}$. On analogy with calcium, the portion of plasma $\mathrm{Zn}$ that is not bound to albumin and $\alpha 2$-macroglobulin should be in equilibrium with the much larger $\mathrm{Zn}$ pools in tissues, and should fall during deprivation as depleted tissues take up more $\mathrm{Zn}$ than plasma. This increased avidity has been demonstrated in the $\mathrm{Zn}$-deficient rat (Senapati, 1986). The levels of plasma protein should not affect this fraction, and so potentially its measurement in a fasting blood sample could be useful (Whitehouse et al. 1983). Unfortunately, the non-protein-bound $\mathrm{Zn}$ is a tiny proportion of the whole, so its 
accurate measurement is easily affected by contamination or binding of $\mathrm{Zn}$ to filters and containers. Nevertheless this method has potential. The latest careful estimates are that this fraction is only $0 \cdot 2 \%$ of total plasma $\mathrm{Zn}$ (Bloxam et al. 1984).

9. Hair and nails. Although levels of toxic metals in hair and skin can indicate body burdens, most agree that measurement of levels of $\mathrm{Zn}$ in the integument are of little value (Solomons, 1979; Dormandy, 1986; Klevay et al. 1987; Hambidge, 1988). The hair is easily contaminated in vivo, cleaning removes intrinsic Zn (Buckley \& Dreosti, 1984; Mikasa et al. 1988), and the content depends on the rate of growth (Erten et al. 1978) and its site (McKenzie, 1978). Nails are no better (Lavis et al. 1986). Unfortunately, the purveyors of commercial assessments of mineral status continue to use hair measurements.

10. Saliva. Similar to measurement of phenytoin levels, levels of $\mathrm{Zn}$ in saliva might reflect levels in plasma. Samples are easily obtained, but are liable to contamination in the mouth and may depend on the protein level and cellular content of saliva (Freeland-Graves et al. 1981) and flow rates. Salivary $\mathrm{Zn}$ cannot be recommended (Solomons, 1979; Baer \& King, 1984; Hambidge, 1988).

\section{FUNCTION TESTS}

1. Electroretinogram. The highest tissue level of $\mathrm{Zn}$ is in the retina, partly because retinol dehydrogenase (EC 1.1.1.105) is a $\mathrm{Zn}$ metalloenzyme. Both vitamin $\mathrm{A}$ and $\mathrm{Zn}$ depletion, therefore, impair dark adaptation by the cones. The electroretinogram when carefully performed is, therefore, a sensitive physiological measure of $\mathrm{Zn}$ function, in which the speed and magnitude of the gradual increasing electrical response to short flashes of light is measured in the dark. The electroretinogram is abnormal in alcoholic cirrhosis (Morrison et al. 1978) when it correlates with leucocyte Zn levels (Keeling et al. 1982), and in experimental $\mathrm{Zn}$ depletion in the cat (Jacobson et al. 1986). Unfortunately, the measurements are not easily performed, and it is difficult to be sure that concomitant vitamin $A$ deficiency is not also affecting the results.

2. Taste acuity. Tissue $\mathrm{Zn}$ deficiency impairs taste and food uptake, so there has been a campaign, chiefly outside scientific literature, to put forward the ability to detect small quantities of zinc sulphate on the tongue as a commercial test of $\mathrm{Zn}$ deficiency (Bryce-Smith \& Hodgkinson, 1986). Most would agree that taste is difficult to measure objectively and that so far the findings are at best unconvincing (Solomons, 1979; Hambidge, 1988).

3. Alkaline phosphatase (EC 3.1.3.1). Alkaline phosphatase is a $\mathrm{Zn}$ metalloenzyme and, therefore, its activity in blood has been measured and related to $\mathrm{Zn}$ levels (Weismann \& Hoyer, 1985). It has not, however, proved useful (Solomons, 1979; Hambidge, 1988), probably because the enzyme is preserved in the face of depletion.

4. Metallothionein I. The metal-binding protein metallothionein is present in most tissues. A small amount circulates in plasma and erythrocytes, and their levels fall in experimental $\mathrm{Zn}$ depletion (Sato et al. 1984). It can be measured by radioimmunoassay (Garvey \& Chang, 1981), but since it is affected by, for instance, a diurnal rhythm and iron intake (Robertson et al. 1989), more work is needed fully to assess its potential in detecting $\mathrm{Zn}$ deficiency in man.

5. Thymulin. The level of this thymic hormone falls in experimental human $\mathrm{Zn}$ deficiency (Prasad et al. 1988), presumably because it is $\mathrm{Zn}$-dependent, and this may prove to be a relatively simple measure of deficiency. 
6. Ethanol clearance. There has been a surprising report that the oral-plasma bioavailability curve of ethanol is increased in human experimental $\mathrm{Zn}$ deficiency so mild that even the levels in leucocytes only slightly fell (Milne et al. 1987). Although this could hardly be used as a clinical test, the results emphasize that $\mathrm{Zn}$ deficiency can affect many functions that could be usefully measured.

\section{Zn KINETICS}

1. Balance studies. Since intestinal $\mathrm{Zn}$ absorption increases in response to $\mathrm{Zn}$ deprivation, so that in the rat nearly $100 \%$ of $\mathrm{Zn}$ can be absorbed from the diet (Senapati, 1986), it should be possible to measure intake and excretion in urine and faeces on a small oral dose of $\mathrm{Zn}$ (Solomons, 1979; Bunker et al. 1987) and conclude whether patients are in positive or negative balance. This is impractical, however, in individual patients outside metabolic units, and results will depend on whether the cause of $\mathrm{Zn}$ deficiency, such as from intestinal malabsorption or increased urinary loss, is corrected. Nevertheless, retention of $\mathrm{Zn}$ was increased in patients with alcoholic cirrhosis (Blendis et al. 1978), suggesting that they were deficient.

3. Plasma bioavailability. The area under the plasma time $v$. concentration curve of $\mathrm{Zn}$ has been used as a proxy for intestinal absorption. On analogy with experimental $\mathrm{Zn}$ deficiency in animals, absorption and hence the plasma curves, should be increased. Surprisingly, therefore, reduced curves have been found in patients with Crohn's disease (Nakamura et al. 1988) and cirrhosis (Sullivan et al. 1979). However, such a Zn tolerance test presupposes a normal rate of plasma clearance, and recently this has been shown to be increased in patients with active Crohn's disease (Nakamura et al. 1988). This could be due either to increased avidity of depleted tissues for $\mathrm{Zn}$, or to the disease itself, which greatly complicates interpretation of the curves. In liver disease, reduced hepatic extraction of $\mathrm{Zn}$ (Keeling et al. 1981) should increase plasma levels, while the increased urinary excretion (Keeling et al. 1980) will increase plasma clearance and reduce the area under the curves. Diabetes mellitus (Kinlaw et al. 1983) and ethambutol (King \& Schwartz, 1987) may do the same.

An interesting method is to administer a mass dose of isotopic $\mathrm{Zn}$ and measure the plasma curves of not only total $\mathrm{Zn}$, but also of the specific activity. This increases with the cold peak, suggesting that the exogenous $\mathrm{Zn}$ is diluted with endogenous $\mathrm{Zn}$ entering the plasma (Van den Hamer et al. 1987). It was suggested that this was derived from $\mathrm{Zn}$ in the mucosal cells, but it might also be due to exchange with $\mathrm{Zn}$ in any tissue. Such calculations in $\mathrm{Zn}$-deficient subjects will be interesting.

2. Plasma clearance. The rate of clearance of cold or isotopic $\mathrm{Zn}$ might measure the avidity of tissues depleted of $\mathrm{Zn}$, with the provisos mentioned previously (Nakamura et al. 1988), although over-analysis of curves (Prasad et al. 1963) should be resisted. Again, however, it would be difficult to use this as a simple test in individual patients. Furthermore, recent work suggests that the distribution of $\mathbf{Z n}$ among tissues can be altered. Thus, valproic acid increases the retention of $\mathrm{Zn}$ in liver (Keen et al. 1989). In women, oral Fe supplementation decreases plasma but not tissue $\mathrm{Zn}$ levels (Bloxam et al. 1989), and ethambutol may increase intestinal absorption and urinary excretion (King \& Schwartz, 1987). In animals, cadmium induces metallothionein and traps $\mathrm{Zn}$ in tissues (Simmer et al. 1986). Similar shifts might explain unexpected reduced leucocyte $\mathrm{Zn}$ levels, such as in polycythaemia (Simmer et al. 1987). 
4. Whole-body turnover. It would be expected that oral or intravenously administered isotopic $\mathrm{Zn}$ would turn over more slowly if $\mathrm{Zn}$ were depleted, because it would be retained more avidly in tissues. However, $\mathrm{Zn}$ has a very long half-life in some tissues, and it will also depend on whether there continues to be increased losses of $\mathrm{Zn}$ in urine (cirrhosis, sickle cell anaemia, tissue metabolism) or faeces (intestinal disease). A sensitive counter is needed (Lykken, 1983) to detect the small amount (5-10 $\mu$ (Ci) $\mathrm{Zn}$ that can safely be administered to man. It is unlikely that all the pools of $\mathrm{Zn}$ in muscle and bone will fully equilibrate with the isotope for many weeks. Nevertheless, studies in man have shown $\mathrm{Zn}$ retention might be used as a proxy for absorption and then whole-body turnover calculated, which may be slower in $\mathrm{Zn}$ deficiency. These are lengthy studies (Aamodt et al. 1982). Our own studies unfortunately suggest that turnover is best related to urinary excretion rates.

5. Specific activity in urine. Following the administration of a small quantity of isotopic $\mathrm{Zn}$, the urinary $\mathrm{Zn}$ specific isotope ratio will rise and then fall to a plateau when urinary $\mathrm{Zn}$ is in equilibrium with plasma $\mathrm{Zn}$, which itself may eventually come into equilibrium with tissue $\mathrm{Zn}$. Using these assumptions the normal whole-body $\mathrm{Zn}$ has been estimated (Mills et al. 1983) to be much lower $(<1 \mathrm{~g})$ than previous estimates, even as low as 100 $\mathrm{mg}$ ! These results are difficult to understand. Perhaps urinary isotopic excretion remains too high because it does not fully equilibrate with all the metal in muscle and particularly in bone.

Thus in the rat, endotoxin can alter the size of $\mathrm{Zn}$ pools with which isotopic $\mathrm{Zn}$ equilibrates (Lowe \& Jackson, 1989), and this could be relevant. The estimated whole-body content was increased in the patients with alcoholic cirrhosis (Mills et al. 1983), in spite of hyperzincuria, and was combined with increased absorption (amount retained at $10 \mathrm{~d}$ ) and a normal turnover rate (measured up to 32 weeks). These results are best explained by increased avidity for the isotope in a depleted tissue, such as bone (Gvozdanovic et al. 1982) or muscle (Senapati, 1986). With the persisting high urinary loss of non-isotopic $\mathrm{Zn}$, whole-body content, calculation of which depends on urinary specific activity, would then be inaccurate.

In conclusion, a simple, reliable clinical measure of $\mathrm{Zn}$ deficiency is lacking. Polymorphonuclear leucocyte $\mathrm{Zn}$ levels are probably at present the most reliable measurement and are increasingly used, but are difficult to measure. If we agree with Solomons (1979) that the response of clinical variables to $\mathrm{Zn}$ supplementation is the best test for detecting deficiency, then $\mathrm{Zn}$ deficiency is worldwide in apparently healthy children (Hambidge et al. 1985; Gibson et al. 1989), in malnutrition (Castillo-Duran et al. 1987; Simmer et al. 1988), and in pregnancy (Simmer \& Thompson, 1985). Supplementation carries the risk of causing $\mathrm{Cu}$ depletion (Anon, 1985) and so selection of individuals needing extra $\mathrm{Zn}$ will be required, but for this a simpler and better test is urgently needed.

\section{REFERENCES}

Aamodt, R. L., Rumble, W. F., Babcock, A. K., Foster, D. M. \& Henkin. R. I. (1982). Effects of oral zinc loading on zinc metabolism in humans. I. Experimental studies. Merabolism 31, 326-334.

Ainley, C. C., Cason, J., Carlsson, L. K.. Slavin. B. M. \& Thompson. R. P. H. (1988). Zinc status in inflammatory bowel disease. Clinical Science 75, 277-283.

Anon (1985). Copper deficiency induced by megadoses of zinc. Nutrition Review's $\mathbf{4 3}, 148-149$. 
Apgar, J. \& Fitzgerald, J. A. (1987). Measure of zinc status in ewes given a low zinc diet throughout pregnancy. Nutrition Research 7, 1281-1290.

Baer, M. T. \& King, J. C. (1984). Tissue zinc levels and zinc excretion during experimental zinc depletion in young men. American Journal of Clinical Nutrition 39, 556-570.

Blendis, L. M., Wesson, D., Doody, M., Allen, L. C., Dietrich, L. \& Goldberg, E.. M. (1978). Zinc deficiency in cirrhosis. Gastroenterology 75, 956.

Bloxam, D. L., Tan, J. C. Y. \& Parkinson, C. E. (1984). Non-protein bound zinc concentration in human plasma and amniotic fluid measured by ultrafiltration. Clinica Chimica Acta 144, 81-93.

Bloxam. D. L.. Williams, N. R.. Waskett, R. J. D., Pattinson-Green. P. M., Morarji, Y. \& Stewart, S. G. (1989). Maternal zinc during oral iron supplementation in pregnancy: a preliminary study. Clinical Science 76. $59-65$.

Bryce-Smith, D. \& Hodgkinson. L. (1986). The Zinc Solution. London: Century Arrow.

Buckley. R. A. \& Dreosti, I. E. (1984). Radioisotopic studies concerning the efficacy of standard washing procedures for the cleaning of hair before zinc analysis. American Journal of Clinical Nutrition 40. 840-846.

Buerk, C. A., Chandy, M. G.. Pearson, E., MacAuly. A. \& Soroff, H. S. (1973). Zinc deficiency: effect on healing and metabolism in man. Surgical Forum 24, 101-102.

Bunker, V. W., Hinks, L. J., Stansfield, M. F., Lawson, M. S. \& Clayton, B. E. (1987). Metabolic balance studies for zinc and copper in housebound elderly people and the relationship between zinc balance and leukocyte zinc concentrations. American Journal of Clinical Nutrition 46, 353-359.

Castillo-Duran, C., Heresi, G., Fisberg, M. \& Oauy, R. (1987). Controlled trial of zinc supplementation during recovery from malnutrition: effects on growth and immune function. American Journal of Clinical Nutrition 45, 602-608.

Crofton. R. W. Clapham, M., Humphries, W. R., Aggett. P. J. \& Mills. C. F. (1983). Leucocyte and tissuc zinc concentrations in the growing pig. Proceedings of the Nutrition Sociery 42, $128 \mathrm{~A}$.

Dormandy. T. L. (1986). Trace clement analysis of hair. British Medical Journal 293, 975-976.

Elia. M., Crozicr, C. \& Neale, G. (1984). Mineral metabolism during short-term starvation in man. Clinica Chimica Acta 139, 37-45.

Erten, J., Arcasoy, A., Cavdar. A. O. \& Cin, S. (1978). Hair zinc levels in healthy and malnourished children. American Journal of Clinical Nutrition 31, 1172-1174.

Everett, G. \& Apgar, J. (1984). Effect of low zinc intake on plasma and leukocyte zinc concentration in pregnant ewes. In Trace Element Analytical Chemistry in Medicine \& Biology, vol. 3. pp. 695-702 [P. Bratter and P. Schramel, editors|. Berlin: Walter de Gruyter.

Fell, G. S., Fleck, A., Cuthbertson, D. P., Queen, K., Morrison, D. P., Bessent, R. G. \& Husain, S. L. (1973). Urinary zinc levels as an indication of muscle catabolism. Lancet $\mathbf{i}, 280-282$.

Flear, C. T. G., Cooke, W. T. \& Quinton, A. (1957). Serum potassium levels as an index of hody content. Lancet i, $458-459$.

Fredricks, R. E., Tanaka, K. R. \& Valentine, W. N. (1964). Variations of human blood cell zinc in disease. Journal of Clinical Investigation 43, 304-315.

Freeland-Graves, J. H., Hendrickson, P. J., Ebangit, M. L. \& Snowden, J. Y. (1981). Salivary zinc as an index of zinc status in women fed a low-zinc diet. American Journal of Clinical Nutrition 34. 312-321.

Garvey, J. S. \& Chang, C. C. (1981). Detection of circulating metallothionein in rats injected with zinc or cadmium. Science 214, 805-807.

Gibson, R. S., Vanderkooy, P. D. S. MacDonald, A. C., Goldman, A., Ryan, B. A. \& Berry. M. (1989). A growth-limiting. mild zinc-deficiency syndrome in some Southern Ontario boys with low height percentiles. American Journal of Clinical Nurrition 49, 1266-1273.

Giugliano, R. \& Millward, D. J. (1984). Growth and zinc homeostasis in the severely Zn-deficient rat. British Journal of Nutrition 52, 545-560.

Golden, B. E. \& Golden, M. H. N. (1981). Plasma zinc, rate of weight gain and the energy cost of tissue deposition in children rccovering from severe malnutrition on a cow's milk or soya protein based diet. American Journal of Clinical Nutrition 34, 892-899.

Golub. M. S., Gershwin, M. E.. Hurley, L. S. Baly, D. L. \& Hendrickx. A. G. (1984). Studies of marginal zinc deprivation in thesus monkeys. I. Influence on pregnant dams. American Journal of Clinical Nutrition 39, $265-280$.

Goode, H. F., Kelleher. J. \& Walker, B. E. (1989a). Zinc concentrations in pure populations of peripheral blood neutrophils, lymphocytes and monocytes. Annals of Clinical Biochemistry 26, 89-95.

Goode, H. F., Kelleher, J., Walker. B. E., Hall, R. I. \& Guillou, P. J. (1989b). Neutrophil zinc is related to the severity of hepatic damage in patients with liver disease. Proceedings of the Nutrition Society 49, 73A. 
Goode, H. F., Penn, N. D., Kelleher, J. \& Walker, B. E. (1989c). A critical assessment of leucocyte zinc as an index of $\mathrm{Zn}$ status in chronically ill hospitalized elderly patients. Proceedings of the Nutrition Sociery 49. $71 \mathrm{~A}$.

Gvozdanovic, S., Gvozdanovic, D., Crofton, R. W., Aggett, P. J., Mowatt, N. A. G. M. \& Brunt, P. W. (1982). Study of zinc kinetics in liver and skeleton in patients with cirrhosis. Nuclear Medicine Communications 3, 127.

Hambidge, K. M. (1988). Assessing the trace element status of man. Proceedings of the Nutrition Society 47. $37-44$.

Hambidge, K. M. Krebs, N. F. \& Walravens, P. A. (1985). Zinc-deficiency. In Proceedings of the XIII International Congress of Nutrition, pp. 513-516 [T. G. Taylor and N. K. Jenkins, editors]. London: John Libbey.

Hess, F. M., King, J. C. \& Margen, S. (1977). Zinc excretion in young women on low zinc intakes and oral contraceptive agents. Journal of Nutrition 107, 1610-1620.

Jackson, M. J., Jones, D. A. \& Edwards, R. H. T. (1981). Zinc excretion as an index of muscle catabolism. Clinical Science 61, 7.

Jackson, M. J., Jones, D. A. \& Edwards, R. H. T. (1982). Tissue zinc levels as an index of body zinc status. Clinical Physiology 2, 333-343.

Jacobson, S. G., Meadows, N. J., Keeling, P. W. N. \& Thompson, R. P. H. (1986). Rod-mediated retinal dysfunction in cats with zinc depletion: comparison with taurine depletion. Clinical Science 71, 559-564.

Jones, R. B., Kecling, P. W. N., Hilton, P. J. \& Thompson, R. P. H. (1981). The relationship between leucocyte and muscle zinc in health and disease. Clinical Science 60, 237-239.

Keeling, P. W. N., Jones, R. B.. Hilton, P. J. \& Thompson, R. P. H. (1980). Reduced leucocyte zinc in liver disease. Gut 21, 56i-564.

Kecling. P. W. N.. O'Day, J., Ruse, W. \& Thompson, R. P. H. (1982). Zinc deficiency and photoreceptor dysfunction in chronic liver disease. Clinical Science 62, 109-111.

Keeling, P. W. N., Ruse, W., Bull, J., Hannigan, B. \& Thompson, R. P. H. (1981). Direct measurement of the hepatointestinal extraction of zinc in cirrhosis and hepatitis. Clinical Science 61, 441-444.

Keen, C. L.. Golub, M. S., Gershwin, M. E., Lonnerdal, B. \& Hurley, L. S. (1988). Studies of marginal zinc deprivation in rhesus monkeys. III. Use of liver biopsy in the assessment of zinc status. American Journal of Clinical Nutrition 47, 1041-1045.

Keen, C. L., Peters, J. M. \& Hurley, L. S. (1989). The effect of valproic acid on ${ }^{65} \mathrm{Zn}$ distribution in the pregnant rat. Journal of Nutrition 119, 607-611.

King, A. B. \& Schwartz, R. (1987). Effects of the antituberculous drug thambutol on zinc absorption, turnover and distribution in rats fed diets marginal and adequate in zinc. Journal of Nutrition 117, 704-708.

Kinlaw, W. B., Levine, A. S., Morley. J. E., Silvis, S. E. \& McClain, C. J. (1983). Abnormal zinc metabolism in type II diabetes mellitus. American Journal of Medicine 75, 273-277.

Klevay, L. M., Bistrian, B. R., Fleming, C. R. \& Neumann, C. G. (1987). Hair analysis in clinical and experimental medicine. American Journal of Clinical Nutrition 46, 233-236.

Lavis, G. J., Ofei, V. \& Bender, D. A. (1986). Differences in the zinc content of different regions of the toe-nail. Proceedings of the Nutrition Society 46, 59A.

Lindh, U. \& Johansson, E. (1987). Trace-element determination in individual peripheral blood cells and possible diagnostic applications. Biological Trace Element Research 12, 351-362.

Lowe, N. M. \& Jackson, M. J. (1989). Plasma ${ }^{65}$ zinc kinetics in zinc-deficient and endotoxin-treated rats. Proceedings of the Nutrition Society 49, 69A.

Lykken, G. 1. (1983). A whole body counting technique using ultralow doses of ${ }^{59} \mathrm{Fe}$ and ${ }^{65} \mathrm{Zn}$ in absorption and retention studies in humans. American Journal of Clinical Nutrition 37, 652-662.

McKenzie, J. M. (1978). Alteration of the zinc and copper concentration of hair. American Journal of Clinical Nutrition 31, 470-476.

Meadows, N. J., Cunnane, S. C., Keeling, P. W. V. \& Thompson, R. P. H. (1983a). The diagnosis of nucleated tissue zinc depletion in man and its effect upon pregnancy. In Zinc Deficiency in Human Subjects, [A. S. Prasad, A. O. Cavdar, G. J. Brewer and P. J. Aggett, editors]. New York: Alan R. Liss.

Meadows, N., Ruse, W., Keeling. P. W. N., Scopes, J. W. \& Thompson, R. P. H. (1983b). Peripheral blood leucocyte zinc depletion in babies with intrauterine growth retardation. Archives of Diseases in Childhood 58, 807-809.

Meadows, N. J., Rusc, W., Smith, M. F., Day, J., Kecling, P. W. N., Scopes, J. W., Thompson, R. P. H. \& Bloxam, D. L. (1981). Zinc and small babies. Lancet ii, 1135-1137.

Mikasa, H., Suzuki. Y., Fujii, N. \& Nishiyama, K. (1988). Adsorption and elution of metals on hair. Biological Trace Element Research 16, 59-66. 
Mills, P. R., Fell, G. S., Bessent, R. G., Nelson, L. M. \& Russell, R. I. (1983). A study of zinc metabolism in alcoholic cirrhosis. Clinical Science 64, 527-535.

Milne, D. B., Canfield, W. K., Gallagher, S. K., Hunt, J. R. \& Klevay, L. M. (1987). Ethanol metabolism in postmenopausal women fed a diet marginal in zinc. American Journal of Clinical Nutrition 46, 688-693.

Milne, D. B., Ralston, N. V. C. \& Wallwork, J. C. (1985a). Zinc content of blood cellular components and lymph node and spleen lymphocytes in severely zinc-deficient rats. Journal of Nutrition 115, 1073-1078

Milnc, D. B., Ralston, N. V. C. \& Wallwork, J. C. (1985h). Zinc content of cellular components of blood: Methods for cell separation and analysis evaluated. Clinical Chemistry 31, 65-69.

Morrison, S. A., Russell, R. M., Carney, E. A. \& Oaks, E. V. (1978). Zinc deficiency: a cause of abnormal dark adaptation in cirrhotics. American Journal of Clinical Nutrition 31, 276-281.

Nakamura, T., Higashi, A., Takano, S., Akagi, M. \& Matsuda, I. (1988). Zinc clearance correlates with clinical severity of Crohn's disease. A kinetic study. Digestive Diseases and Sciences 33, 1520-1524.

Pai, L. H. \& Prasad, A. S. (1988). Cellular zinc in patients with diabetes mellitus. Nutrition Research 8 , 889-897.

Paton, A. (1981). Mission to Belsen 1945. British Medical Journal 283, 1656-1659.

Pironi, L., Miglioli, M., Cornia, G. L., Ursitti, M. A.. Tolomelli, M., Piazzi, S. \& Barbara, L. (1987). Urinary zinc excretion in Crohn's disease. Digestive Diseases and Sciences 32, 358-362.

Prasad, A.. Meftah. S., Abdallah, J., Kaplan, J., Brewer, G. J., Bach, J. F. \& Dardenne, M. (1988). Serum thymulin in human zinc deficiency. Journal of Clinical Investigation 82, 1202-1210.

Prasad, A., Miale, A., Farid, Z., Sandstead, H. H. \& Schulert, A. R. (1963). Zinc metabolism in patients with the syndrome of iron deficiency anemia, hepatosplenomegaly, dwarfism, and hypogonadism. Journal of Laboratory and Clinical Medicine 61, 537-549.

Prasad, A. S., Rabbani, P., Abbasii, A., Bowersox, E. \& Fox, M. R. S. (1978). Experimental zinc deficiency in humans. Annals of Internal Medicine 89, 483-490.

Robertson, A., Morrison. J. N., Wood, A. M. \& Bremner, I. (1989). Effects of iron deficiency on metallothionein-I concentrations in blood and tissues of rats. Journal of Nutrition 119, 439-445.

Sato, M. . Mehra, R. K. \& Bremner, I. (1984). Measurement of plasma metallothionein-I in the assessment of the zinc status of zinc-deficient and stressed rats. Journal of Nutrition 114, 1683-1689.

Senapati, A. (1986). Zinc in growth and healing. PhD Thesis, London.

Senapati, A., Jenner. G. \& Thompson, R. P. H. (1989). Zinc in the elderly. Quarterly Journal of Medicine 70, 81-87.

Simmer, K., Carlsson, L. \& Thompson, R. P. H. (1986). Interaction of cadmium and zinc in pregnancy. Clinical Science 70, 50-51P.

Simmer, K., Khanums, L. C. \& Thompson, R. P. H. (1988). Nutritional rehabilitation in Bangladesh - the importance of zinc. American Journal of Clinical Nutrition 47, 1036-1040.

Simmer, K., Pcarson, T. C., Wheeler, M. J. \& Thompson, R. P. H. (1987). Zinc status in polycythaemia. European Journal of Haematology 38, 433-436.

Simmer, K. \& Thompson, R. P. H. (1985). Maternal zinc and intrauterine growth retardation. Clinical Science 68, 395-399.

Solomons, N. W. (1979). On the assessment of zinc and copper nutriture in man. American Journal of Clinical Nutrition 32, 856-871.

Sullivan, J. F., Jetton, M. M. \& Burch, R. E. (1979). A zinc tolerance test. Journal of Laboratory and Clinical Medicine 93, 485-492.

Tuttle, S.. Aggett, P. J., Campbell, D. \& MacGillivray, I. (1985). Zinc and copper nutrition in human pregnancy: a longitudinal study in normal primigravidae and in primigravidae at risk of delivering a growth retarded baby. American Journal of Clinical Nutrition 41, 1032-1041.

Van den Hamer, C. J. A., Kroon, J. J. \& Tjioe, P. S. (1987). An oral zinc loading test using an enriched stable zinc isotope. In Trace Element Analytical Chemistry in Medicine \& Biology, vol. 4, pp. 247-253 |P. Bratter and P. Schramel, editors]. Berlin: Walter de Gruyter.

Wallwork, J. C. (1987). Appraisal of the methodology and applications for measurement of the zinc content of blood components as indicators of zinc status. Biological Trace Element Research 12, 335-350.

Weismann, K. \& Hoyer, H. (1985). Serum alkaline phosphatase and serum zinc levels in the diagnosis and exclusion of zinc deficiency in man. American Journal of Clinical Nutrition 41, 1214-1219.

Wells, J. L., James, D. K. Luxton, R. \& Pennock, C. A. (1987). Maternal leucocyte zinc deficiency at start of third trimester as a predictor of fetal growth retardation. British Medical Journal 294, 1054-1056.

Whitehouse, R. C., Prasad, A. S. \& Cossack, Z. T. (1983). Determination of ultrafiltrable zinc in plasma by flameless atomic absorption spectrophotometry. Clinical Chemistry 29, 1974-1977. 
Widdowson, E. M., McCance, R. A. \& Spray, C. M. (1951). The chemical composition of the human body. Clinical Science 10, 113-125.

Yunice, A. A., King, R. W., Kraikitpanitch, S., Haygood, C. C. \& Lindeman. R. D. (1978). Urinary zinc excretion following infusions of zinc sulfate. cysteine, histidine, or glycine. American Journal of Physiology 235, F40-45. 